\title{
Viruses Infecting Cucurbits in Samsun, Turkey
}

M. A. Sevik and M. Arli-Sokmen, Ondokuz Mayis Universitesi, Ziraat Fakultesi, Bitki Koruma Bolumu, 55139 Samsun, Turkey

\begin{abstract}
Sevik, M. A., and Arli-Sokmen, M. 2003. Viruses infecting cucurbits in Samsun, Turkey. Plant Dis. 87:341-344.

To detect cucurbit viruses and determine their incidence, surveys were conducted in 45 fields in 18 villages in Samsun province, Turkey from July to October in 1999 and 2000. Watermelon mosaic virus (WMV), Zucchini yellow mosaic virus (ZYMV), and Cucumber mosaic virus (CMV) were detected in cucurbits after analyzing 165 samples by enzyme-linked immunosorbent assay. WMV, ZYMV, and CMV were detected in 53.9, 38.8, and $20.6 \%$ of samples tested, respectively. ZYMV and WMV infections were detected in all cucurbit species, but CMV was not detected in any samples of watermelon and pumpkin.
\end{abstract}

Additional keywords: Cucurbitaceae, serological testing, virus disease

Samsun province is one of the main vegetable-growing areas of Turkey and is located in the northern part of the country (Fig. 1). The estimated annual vegetable production in the region is $1,170,202$ tons, and approximately one-quarter of the crops grown belongs to the family Cucurbitaceae (2). Approximately $80 \%$ of commercial cucumber (Cucumis sativus L.), melon (Cucumis melo L.), squash (Cucurbita pepo L.), and watermelon (Citrullus lanatus (Thunb.) Matsum. \& Nakai var. Lanatus; Synonym: $C$. vulgaris Schrad.) production areas in Samsun province are in the Bafra, Carsamba, Terme, and Tekkekoy districts, and $96.6 \%$ of pumpkin (Cucurbita maxima Duchesne var. maxima) are grown in the Kavak, Terme, Carsamba, and Bafra districts (Provincial Directorate of The Ministry of Agriculture and Rural Affairs, unpublished data). Viruses have become a problem in cucurbits in Samsun in recent years. The most common symptoms in infected plants are leaf mosaics and distortions, reduction in fruit size, and abnormal fruit color and shape.

Virus diseases are also a major cause of economic losses in commercial cucurbit production around the world, and 30 viruses are known to infect cucurbit crops in field conditions (16). Prior to 1969, the only cucurbit-infecting virus detected in Turkey was Cucumber mosaic virus (CMV; 15). Then, in surveys made in

Corresponding author: M. Arli-Sokmen

E-mail: mirays@omu.edu.tr

This research was supported by Ondokuz Mayis University Research Fund (Project no: Z-297).

Accepted for publication 2 October 2002.

Publication no. D-2003-0130-01R

(c) 2003 The American Phytopathological Society northwest Turkey, Watermelon mosaic virus-2 (renamed Watermelon mosaic virus [WMV]) was found in 142 samples of 262 tested (18). Zucchini yellow mosaic virus (ZYMV) was detected in squash grown in greenhouses on the Mediterranean coast of the country (6). Three other viruses recorded in Turkey are Watermelon mosaic virus-1 (renamed Papaya ring spot virus; [PRSV]; (9), Cucumber vein yellowing virus (23), and Melon mosaic virus (24). In 1992, Tomato ringspot virus and Tomato black ring virus were detected only in cucumber (11). To date, there is only one study of viruses infecting cucurbits in Samsun. That study used symptomatological observations and sap-inoculation tests to show that cucurbit crops were infected with CMV, WMV, and ZYMV (4). Despite this information, there is no data about the incidence and distribution of these viruses in field-grown cucurbits in different locations in Samsun. Therefore, our study was conducted to identify the major virus diseases and their incidence in cucurbits using enzyme-linked immunosorbent assay (ELISA).

\section{MATERIALS AND METHODS}

Surveys and sample collection. Fields were selected randomly from various locations in 18 villages in Bafra, Carsamba, Terme, and Tekkekoy districts (Fig. 1). Surveys were performed in 45 fields containing cucumber, melon, pumpkin, squash, and watermelon plants.

Leaf samples were collected from July through October in 1999 and 2000. The sampling method described by Sammons and Barnett (21) was applied in this study, except at least 10 plants per 0.5 ha were sampled, instead of 12 plants per hectare (Table 1). Samples were collected randomly along field diagonals, and two or three leaves from the shoot apex of each plant were taken. In addition, five plants showing virus symptom were selected from border rows of each field to detect viruses that may have been missed by the random collections (21); however, they were not used in calculating virus incidence data. Symptoms of plants were re-

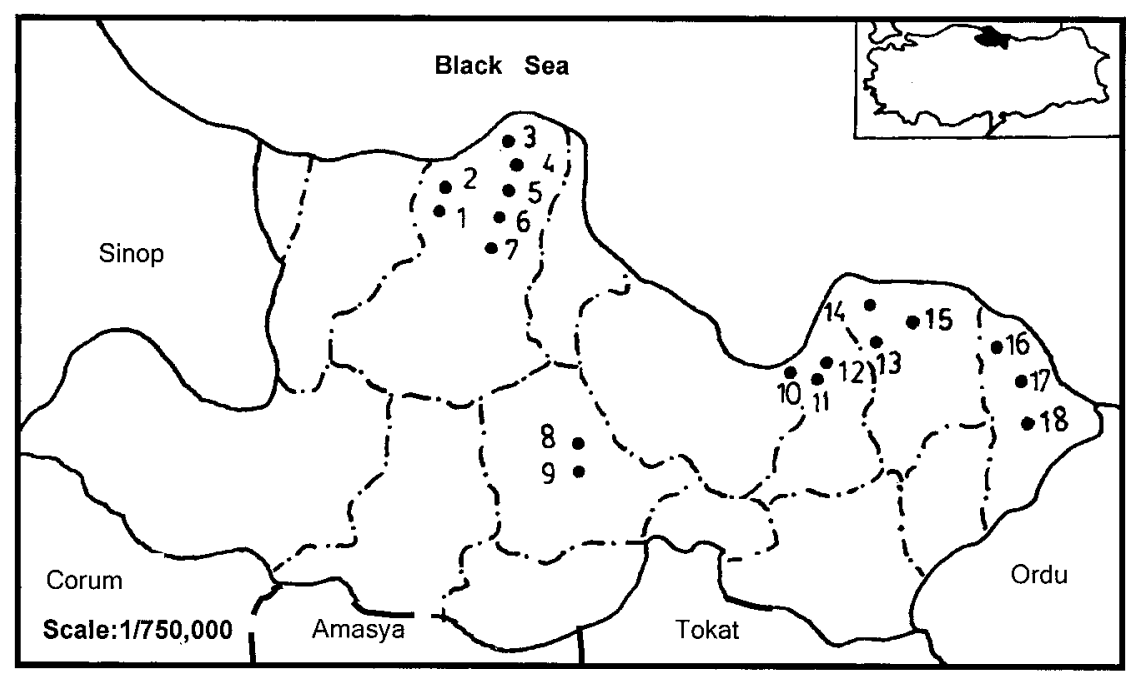

Fig. 1. Map of Samsun province showing villages in five districts in which surveys were conducted. Map in the corner indicates the location of Samsun province in Turkey. Bafra District: $1=$ Kuscular, $2=$ Karaburc, 3 = Altınova, $4=$ Yeşilyazı, $5=$ Karıncak, $6=$ Karpuzlu, $7=$ Agıllar; Kavak District: 8 = Cakall1, $9=$ Karapınar; Tekkekoy District: $10=$ Kutlukent, $11=$ Merkez, $12=$ Gelemen; Carsamba District: $13=$ Damlatas, $14=$ Ahubaba, $15=$ A. Dikencik; Terme District: $16=$ Gecmiş, $17=$ Sutozu, $18=$ Uzungazi. 
corded before putting leaf samples into plastic bags and storing in a freezer $\left(-20^{\circ} \mathrm{C}\right)$.

Serological testing. The double antibody sandwich (DAS)-ELISA method was performed according to Clark and Adams (5) and instructions of the antisera producer (Loewe Biochemica, Sauerlach, Germany), except that extraction buffer included $0.1 \%$ nonfat dry milk instead of bovine serum albumin (3). Cucumber, melon, pumpkin, squash, and watermelon samples were ground in mortar with extraction buffer (PBST: $0.13 \mathrm{M} \mathrm{NaCl}$, $0.014 \mathrm{M} \mathrm{KH}_{2} \mathrm{PO}_{4}, 0.08 \mathrm{M} \mathrm{Na}_{2} \mathrm{HPO}_{4}, 0.002$ $\mathrm{M}$ KCL, pH 7.4) containing $0.05 \%$ Tween 20 and $0.1 \%$ nonfat dry milk and added to wells, which were precoated with CMV-, WMV-2-, or ZYMV-specific polyclonal antisera diluted in carbonate buffer $(\mathrm{pH}$ : 9.6). Plates (Nunc Microwell, Roskilde, Denmark) were incubated at $4^{\circ} \mathrm{C}$ overnight and washed four times with PBST-Tween 20 buffer. Then, plates were coated with

Table 1. Numbers of fields surveyed and samples collected and tested in each district/village

\begin{tabular}{|c|c|c|c|c|}
\hline Districts, villages & $\begin{array}{l}\text { No. of fields } \\
\text { surveyed }\end{array}$ & $\begin{array}{c}\text { Total area } \\
\text { surveyed (ha) }\end{array}$ & $\begin{array}{c}\text { No. of samples } \\
\text { collected }\end{array}$ & $\begin{array}{c}\text { No. of samples } \\
\text { tested }\end{array}$ \\
\hline \multicolumn{5}{|l|}{ Bafra } \\
\hline Karaburc & 7 & 3.0 & 86 & 29 \\
\hline Yeşilyazı & 7 & 3.7 & 88 & 29 \\
\hline Altınova & 2 & 0.5 & 20 & 6 \\
\hline Karpuzlu & 1 & 0.7 & 15 & 5 \\
\hline Karıncak $^{a}$ & 1 & 0.5 & 5 & 1 \\
\hline Ağ́llar & 1 & 0.5 & 5 & 1 \\
\hline Kuşcular ${ }^{\mathrm{a}}$ & 1 & 0.1 & 10 & 3 \\
\hline \multicolumn{5}{|l|}{ Carsamba } \\
\hline Ahubaba & 5 & 2.0 & 61 & 17 \\
\hline A.Dikencik & 5 & 1.5 & 56 & 15 \\
\hline Damlatas & 2 & 1.0 & 30 & 10 \\
\hline \multicolumn{5}{|l|}{ Tekkekoy } \\
\hline Kutlukent & 3 & 0.7 & 26 & 11 \\
\hline Gelemen & 1 & 0.5 & 15 & 5 \\
\hline Merkez & 1 & 0.6 & 15 & 5 \\
\hline \multicolumn{5}{|l|}{ Terme } \\
\hline Gecmis $^{\mathrm{a}}$ & 2 & 0.3 & 13 & 6 \\
\hline Sutozu $^{\mathrm{a}}$ & 1 & 0.3 & 10 & 3 \\
\hline Uzungazi $^{\mathrm{a}}$ & 1 & 0.1 & 8 & 3 \\
\hline \multicolumn{5}{|l|}{ Kavak } \\
\hline Karapinar & 3 & 0.8 & 35 & 11 \\
\hline Çakallı & 1 & 0.7 & 15 & 5 \\
\hline Total & 45 & 17.5 & 513 & 165 \\
\hline
\end{tabular}

${ }^{a}$ Samples collected in these villages were less than 10 plants per 0.5 ha. Also, size of some fields was smaller than 0.5 ha.

Table 2. Range of absorbance values of negative controls, and positive and negative samples

\begin{tabular}{llll}
\hline & \multicolumn{3}{c}{ Absorbance values } \\
\cline { 2 - 4 } Plant, virus $^{\mathbf{a}}$ & Negative controls $^{\mathbf{b}}$ & Positive samples $^{\mathbf{c}}$ & Negative samples \\
\hline Cucumber & & & \\
CMV & $0.117-0.120(3)$ & $0.510-1.359(7)$ & $0.078-0.164(29)$ \\
WMV & $0.073-0.107(3)$ & $0.157-0.952(18)$ & $0.073-0.156(18)$ \\
ZYMV & $0.092-0.108(3)$ & $0.189-1.442(21)$ & $0.074-0.183(15)$ \\
Melon & & & \\
CMV & $0.084-0.101(3)$ & $0.222-1.026(10)$ & $0.065-0.171(21)$ \\
WMV & $0.067-0.126(3)$ & $0.206-3.056(17)$ & $0.070-0.211(14)$ \\
ZYMV & $0.146-0.164(3)$ & $0.331-3.415(11)$ & $0.065-0.320(20)$ \\
Pumpkin & & & \\
CMV & $0.245-0.257(2)$ & $\ldots$ & $0.068-0.389(34)$ \\
WMV & $0.079-0.102(2)$ & $0.161-0.779(11)$ & $0.092-0.175(23)$ \\
ZYMV & $0.111-0.121(2)$ & $0.248-0.825(11)$ & $0.069-0.205(23)$ \\
Squash & & & \\
CMV & $0.062-0.130(3)$ & $0.195-0.943(17)$ & $0.085-0.195(16)$ \\
WMV & $0.069-0.114(3)$ & $0.147-1.651(28)$ & $0.079-0.173(5)$ \\
ZYMV & $0.064-0.141(3)$ & $0.185-0.658(11)$ & $0.061-0.253(22)$ \\
Watermelon & & & \\
CMV & $0.063-0.091(2)$ & $\ldots$ & $0.061-0.144(31)$ \\
WMV & $0.070-0.089(2)$ & $0.149-1.129(15)$ & $0.067-0.175(16)$ \\
ZYMV & $0.066-0.076(2)$ & $0.154-1.165(10)$ & $0.063-0.145(21)$ \\
\hline
\end{tabular}

a Cucumber mosaic virus (CMV), Watermelon mosaic virus (WMV), and Zucchini yellow mosaic virus (ZYMV).

${ }^{\mathrm{b}}$ Numbers in parenthesis indicate the numbers of individual experiments in which different negative controls for each cucurbit species were used.

${ }^{c}$ Numbers in parenthesis indicate the numbers of positive and negative samples determined in the tests. alkaline phosphatase conjugated antibody diluted in extraction buffer and incubated for $2 \mathrm{~h}$ at $37^{\circ} \mathrm{C}$. After washing, $p$ nitrophenyl phosphate in diethanolamine substrate buffer $(0.5 \mu \mathrm{g} / \mathrm{ml}, \mathrm{pH}$ : 9.8$)$ was added to each well and incubated at room temperature for 30 to $120 \mathrm{~min}$. Absorbance values were read at $405 \mathrm{~nm}$ using a microplate reader (Tecan Spectra II, Grödig/Salzburg, Austria). Virus-free cucurbit species grown in an insect-proof growth chamber were used as negative controls. Samples were considered to be positive when the absorbance at $405 \mathrm{~nm}$ $\left(A_{405}\right)$ values exceeded the mean of the negative controls by at least a factor of two $(1,8,21)$.

\section{RESULTS}

Virus detection and occurrence in cucurbits. A total of 45 fields (17.5 ha) were surveyed and 513 plant samples were randomly collected during the surveys. These plants were used to make subsamples due to a limited supply of reagents. The number of samples taken from each field was reduced about threefold without regard for disease status (Table 1). Subsamples consisted of 165 plants, all of which were tested by DAS-ELISA. The results of serological tests showed that cucurbit plants were infected with CMV, WMV, and ZYMV in Samsun. Tests were conducted using several negative controls for each plant species. Therefore, the range of absorbance values of negative controls varied from 0.062 to 0.257 at $405 \mathrm{~nm}$, depending on cucurbit species and antiserum used. Positive samples gave absorbance values of 0.147 to 3.931 (Table 2).

The incidence of these viruses in the samples of commercially grown cucurbit plants is shown in Table 3. In Cucumis melo, Citrullus vulgaris, and Cucurbita pepo, WMV was the most prevalent virus and was detected in 17 of 31,15 of 31 , and 28 of 34 plants, respectively. In all, 11 samples of $C$. melo and C. pepo and 10 samples of $C$. vulgaris were infected with ZYMV. Of the 36 Cucumis sativus samples tested, 21 plants were infected with ZYMV, 18 with WMV, and 7 with CMV. The number of Cucurbita maxima samples found to be positive for either WMV or ZYMV was the same (11 of 33). CMV was the third most prevalent virus in C. melo, but second in $C$. pepo. It was not detected in any samples of $C$. maxima and $C$. vulgaris (Table 3 ). WMV was the most common virus in all of samples collected during the surveys and $53.9 \%$ of the samples were infected with WMV. With ZYMV and CMV, 38.8 and $20.6 \%$ of the samples were infected, respectively (Table 3).

WMV, ZYMV, and CMV were detected in 33,30 , and 12 of 45 fields surveyed, respectively. Forty fields had plants infected with at least one of these three viruses. The percentages of single infections 
were $22.4 \%$ (WMV), $14.5 \%$ (ZYMV), and $1.8 \%$ (CMV) in the samples. Of the 165 plants, 42 had double virus infections. The most common double infection was ZYMV + WMV (14.5\%). The percentages of $\mathrm{CMV}+\mathrm{WMV}$ and CMV + ZYMV double infections were 9.1 and $1.8 \%$, respectively. The results of DAS-ELISA showed that 13 plants $(7.9 \%$ of the samples) were infected with ZYMV, WMV, and CMV (Table 4).

\section{DISCUSSION}

WMV was the most widespread virus in our study. Similarly, Grafton-Cardwell et al. (12) found that WMV was the most prevalent virus among four viruses (CMV, PRSV, WMV, and ZYMV) in three melongrowing regions in the Central Valley of California. They observed triple virus infections in $7.2 \%$ of the samples. In the survey conducted in 25 fields in South Carolina for viruses infecting yellow summer squash, WMV was found in higher incidence than three other viruses, CMV, PRSV, and Tobacco ringspot virus (TRSV). WMV was identified in 22 fields, followed by CMV in 11 fields, PRSV in 9 fields, and TRSV in 1 field (21). Purcifull et al. (20) tested 162 Cucurbita pepo and 67 Citrillus lanatus samples collected in Florida during surveys in 1991 to 1997 . PRSV (33.9\%), WMV (37.6\%), ZYMV (30.2\%), and CMV
(12.9\%) were detected in C. pepo and PRSV (11.9\%), WMV (59.7\%), and ZYMV $(34.3 \%)$ in C. lanatus.

The current study was the first to show the provincial distribution of cucurbit viruses in the Samsun region. CMV, WMV, and ZYMV were first detected in cucurbits in Samsun in 1998 (4). Serological tests in our study confirmed these results and supplied information on the relative incidence and occurrence of these viruses. The results of the previous study were based on symptomatological observations in the field and biological test methods only and did not provide data on the relative occurrence of these viruses in different locations of the region.

Plants with triple infections showed more severe leaf and fruit symptoms in our study than did plants infected with just one or two of the viruses. These observations suggest that yield is probably lost because of synergistic virus effect, as reported by Luis-Arteaga et al. (17). Also, fruit and leaf symptoms of ZYMV-infected cucurbit plants were more obvious, whereas plants infected with WMV alone produced milder symptoms in our work. These results may indicate that ZYMV isolates infecting cucurbits in the region were more virulent. ZYMV also was shown to be an aggressive and virulent pathogen in New Jersey by Davis and Mizuki (7).

Table 3. Occurrence of viruses on different cucurbit species grown in Samsun ${ }^{\mathrm{a}}$

\begin{tabular}{lcccc}
\hline Species & No. of samples tested & WMV & ZYMV & CMV \\
\hline Cucumis melo & 31 & 17 & 11 & 10 \\
Citrillus vulgaris & 31 & 15 & 10 & 0 \\
Cucumis sativus & 36 & 18 & 21 & 7 \\
Cucurbita pepo & 34 & 28 & 11 & 17 \\
Cucurbita maxima & 33 & 11 & 11 & 0 \\
Total & 165 & 89 & 64 & 34 \\
Percent infected & $\ldots$ & 53.9 & 38.8 & 20.6
\end{tabular}

a Watermelon mosaic virus (WMV), Zucchini yellow mosaic virus (ZYMV), and Cucumber mosaic virus (CMV).
Viruses other than CMV, WMV, and ZYMV likely infect cucurbits in the region. Some samples that showed virus-like symptoms did not react with three antisera used in serological tests. But, antisera specific to the other cucurbit viruses were not available in the present study. Also, various vegetable species are grown in adjacent fields along cucurbit plots and viruses infecting these plants also may infect cucurbits in nature, such as Tomato spotted wilt virus (TSWV; 19) and Tomato leaf curl virus (22). TSWV recently was detected in pepper and some weed hosts growing in the region by using TSWVspecific antisera (M. Arli-Sokmen, unpublished results).

The percentages of plants infected with at least one of the three viruses (CMV, WMV, and ZYMV) in Carsamba, Tekkekoy, Kavak, Bafra, and Terme districts were $88.1,76.2,75.0,66.2$, and $41.6 \%$, respectively. These results revealed that cucurbits grown in commercial fields commonly were infected with viruses in Samsun. All viruses detected in the current study were spread efficiently by aphids and mechanical inoculation $(13,14)$. Unfortunately, growers in the region are not aware of how viruses spread from plant to plant and do not know about precautions to control virus transmission. Weeds have important role on virus epidemiology and are a common problem in vegetable-growing areas in Samsun. Attempts to control weeds have not been effective (H. Mennan, personal communication). CMV naturally infects many plants, including cereals, forages, woody and herbaceous ornamentals, vegetables, and fruit crops (14). WMV has the advantage of having a wider host range than ZYMV (12). In the current study, CMV was found to be the third most widespread virus in infected plants. Therefore, it was hypothesized that WMV and ZYMV are found more commonly in

Table 4. Occurrence of viruses in samples collected during surveys from 45 fields selected randomly in 18 villages in Samsun province ${ }^{\mathrm{a}}$

\begin{tabular}{|c|c|c|c|c|c|c|c|c|}
\hline Village & No. of samples tested & CMV & ZYMV & WMV & $\mathrm{CMV}+\mathrm{ZYMV}$ & CMV + WMV & ZYMV + WMV & CMV + ZYMV + WMV \\
\hline Karaburc & 29 & 1 & 3 & 6 & 1 & 1 & 4 & 2 \\
\hline Yeşilyazı & 29 & 1 & 4 & 9 & 0 & 1 & 5 & 3 \\
\hline Altınova & 6 & 0 & 0 & 3 & 0 & 0 & 2 & 0 \\
\hline Karpuzlu & 5 & 1 & 1 & 1 & 0 & 0 & 0 & 0 \\
\hline Karıncak & 1 & 0 & 0 & 0 & 0 & 0 & 0 & 0 \\
\hline Kuscular & 3 & 0 & 0 & 0 & 0 & 0 & 0 & 0 \\
\hline Ağıllar & 1 & 0 & 0 & 0 & 0 & 0 & 0 & 0 \\
\hline Ahubaba & 17 & 0 & 6 & 4 & 0 & 0 & 3 & 0 \\
\hline A.Dikencik & 15 & 0 & 8 & 2 & 0 & 0 & 4 & 0 \\
\hline Damlatas & 10 & 0 & 0 & 2 & 0 & 7 & 0 & 1 \\
\hline Kutlukent & 11 & 0 & 0 & 2 & 0 & 1 & 4 & 4 \\
\hline Gelemen & 5 & 0 & 0 & 0 & 1 & 1 & 1 & 2 \\
\hline Merkez & 5 & 0 & 0 & 0 & 0 & 0 & 0 & 0 \\
\hline Uzungazi & 3 & 0 & 0 & 1 & 1 & 0 & 1 & 0 \\
\hline Sutozu & 3 & 0 & 0 & 1 & 0 & 0 & 0 & 0 \\
\hline Gecmis & 6 & 0 & 0 & 0 & 0 & 0 & 0 & 0 \\
\hline Karapınar & 11 & 0 & 2 & 1 & 0 & 4 & 0 & 1 \\
\hline Cakallı & 5 & 0 & 0 & 4 & 0 & 0 & 0 & 0 \\
\hline Total & 165 & 3 & 24 & 37 & 3 & 15 & 24 & 13 \\
\hline Percent infection & $\ldots$ & 1.8 & 14.5 & 22.4 & 1.8 & 9.1 & 14.5 & 7.9 \\
\hline
\end{tabular}

${ }^{a}$ Cucumber mosaic virus (CMV), Watermelon mosaic virus (WMV), and Zucchini yellow mosaic virus (ZYMV). 
the region because they are transmitted more efficiently from weed hosts to cucurbits by aphids than is CMV. In a previous study, some CMV isolates containing necrogenic satellite RNAs obtained from tomato were transmitted less efficiently by aphids and accumulated in lower concentrations than isolates without satellites (10). Similar difference in aphid transmissibility could be one of the reasons that CMV was a less prevalent virus in our study.

\section{ACKNOWLEDGMENTS}

We thank Ondokuz Mayis University Research Fund for supporting this project and the Turkish Ministry of Agriculture and Rural Affairs for supplying transportation during surveys.

\section{LITERATURE CITED}

1. Al-Shanwan, I. M., Abdalla, O. A., and AlSaleh, M. A. 1995. Response of greenhousegrown cucumber cultivars to an isolate of zucchini yellow mosaic virus (ZYMV). Plant Dis. 79:898-901.

2. Anonymous, 1999. T.C. Tarımsal Yapı ve Uretim. Basbakanlik Devlet Istatistik Enstitusu Yayinlari. No: 2457, 588. sayfa DIE Matbaasi, Ankara, Turkey.

3. Arif, M., Torrance, L., and Reavy, B. 1994. Improved efficiency of detection of potato mop-top furovirus in potato tubers and in the roots and leaves of soil-bait plants. Potato Res. 37:373-381.

4. Citir, A., Kutluk, N. D., Saglam, N., and Ilbagi, H. 1998. Amasya, Corum, Samsun ve Tokat illerinde hiyar ve kabak kültürlerinde görülen virus hastaliklarinin simptomatolojik ve biyolojik yöntemlerle tanilari. Turkiye VIII. Fitopatoloji Kongresi. Ankara, 331-335.

5. Clark, M. F., and Adams, A. N. 1977. Characteristics of the microplate method of EnzymeLinked Immunosorbent Assay for the detec- tion of plant viruses. J. Gen. Virol. 34:475483.

6. Davis, R. F. 1986. Partial characterization of zucchini yellow mosaic virus isolated from squash in Turkey. Plant Dis. 70:735-738.

7. Davis, R. F., and Mizuki, M. K. 1987. Detection of cucurbit viruses in New Jersey. Plant Dis. 71:40-44.

8. Davis, R. F., and Yilmaz, M. A. 1984. First report of zucchini yellow mosaic virus in Turkey. Plant Dis. 68:537-537.

9. Erdiller, G., and Ertunc, F. 1988. Identification of muskmelon viruses in Ankara province. J. Turk. Phytopathol. 17:4756.

10. Escriu, F., Perry, K. L., and Garcia-Arenal, F. 2000. Transmissibility of cucumber mosaic virus by Aphis gossypii correlates with virus accumulation and is affected by the presence of its satellite RNA. Phytopathology 90:10681072.

11. Fidan, U. 1995. Virus diseases of vegetables in greenhouses in Izmir and Mugla. J. Turk. Phytopathol. 24:7-14

12. Grafton-Cardwell, E. E., Perring, T. M., Smith, R. F., Valencia, J., and Farrar, C. A. 1996. Occurrence of mosaic viruses in melons in the Central Valley of California. Plant Dis. 80:1092-1097.

13. Hollings, M., and Brunt, A. A. 1981. Potyviruses. Pages 731-807 in: Handbook of Plant virus Infections and Comparative Diagnosis. E. Kurstak, ed. Elsevier/North Holland Biomedical Press, Amsterdam, The Netherlands.

14. Kaper, J. M., and Waterworth, H. E. 1981. Cucumoviruse. Pages 257-332 in: Handbook of Plant virus Infections and Comparative Diagnosis. E. Kurstak, ed. Elsevier/North Holland Biomedical Press, Amsterdam, The Netherlands.

15. Kurcman, S. 1977. Determination of virus diseases on cultural plants in Turkey. J. Turk. Phytopathol. 6:25-46.

16. Lovisolo, O. 1980. Virus and viroid diseases of cucurbits. Acta Hortic. 88:33-82.

17. Luis-Arteaga, M., Alverez, J. M., AlansoPrados, J. L., Bernal, J. J., Garcia-Arenal, F. Lavina, A., Batlle, A., and Moriones, E. 1998. Occurrence, distribution, and relative incidence of mosaic viruses infecting field-grown melon in Spain. Plant Dis. 82:979-982.

18. Nogay, A., and Yorganci, U. 1984. Investigations on the identification, seed transmission and host range of viruses infecting the culture plants in the Cucurbitaceae in Marmara region. 1. The identification of viruses infecting cucurbits in Marmara region. J. Turk. Phytopathol. 13:9-28.

19. Pappu, S. S., Pappu, H. R, Gitaitis, R. D., and Gay, J. D. 1998. First report of tomato spotted wilt tospovirus infection of watermelon in Georgia. Plant Dis. 82:351-351.

20. Purcifull, D. E., Heibert, E., Petersen, M. A., Simone, G. W., Kucharek, T. A., Gooch, M. D., Crawford, W. E., Beckham, K. A., and De Sa, P. B. 1998. Partial characterization of a distinct potyvirus isolated from watermelon in Florida. Plant Dis. 82:1386-1390.

21. Sammons, B., Barnett, O. W., Davis, R. F., and Mizuki, M. K. 1989. A survey of viruses infecting yellow summer squash in South Carolina. Plant Dis. 73:401-404.

22. Samretwanich, K., Chiemsombat, P., Kittipakorn, K., and Ikegami, M. 2000. Yellow leaf disease of cantaloupe and wax gourd from Thailand caused by tomato leaf curl virus. Plant Dis. 84:200-200.

23. Yilmaz, M. A., Baloglu, S., Ozaslan, M., and Guldur, M. E. 1995. GAP Bolgesinde kültür bitkilerinde belirlenen virusler. GAP Bolgesi Bitki Koruma Sorunlar• ve Cozum Onerileri Sempozyumu. Sanl•urfa-Turkiye, 241-250.

24. Yilmaz, M. A., Ozaslan, M., and Baloglu, S. 1991. Cukurova bolgesinde yetistiriciligi yapilan kavun, karpuz ve hiyar bitkilerine zararlı yeni bir virus hastaligi. Turkiye VI Fitopatoloji Kongresi. Izmir-Turkiye, 387 391. 